\section{Elective affinities: exploring the matching between entrepreneurs and investors in equity crowdfunding}

Matchings in equity crowdfunding

\author{
Giancarlo Giudici, Massimiliano Guerini and Cristina Rossi-Lamastra \\ School of Management, Politecnico di Milano, Milan, Italy
}

Received 17 August 2019 Revised 30 November 2019 11 December 2019 Accepted 12 December 2019

\begin{abstract}
Purpose - The authors investigate whether matchings in equity crowdfunding are more likely to happen if homophily exists between investors and investees. They focus on gender, age and geographical proximity as crucial dimensions of similarity among individuals and thus of homophily. Furthermore, they investigate whether the effect of homophily depends on the risk of opportunism, which investors allegedly attribute to proponents basing on their area of residence.

Design/methodology/approach - The authors analyze a hand-collected database of 13 equity crowdfunding campaigns launched by Italian innovative start-ups from January 2013 to June 2016, which includes information about 384 equity crowdfunding investments carried out by 361 different investors.

Findings - The authors find a significant effect of geographical proximity and age similarity in explaining the probability that an investor finances a campaign. Moreover, these effects are particularly relevant if the proponent is located in areas characterized by a high risk of opportunistic behavior. Interestingly enough, they do not detect any significant effect related to gender.

Originality/value - In this paper, the authors have the unique opportunity to analyze a whole market (the Italian market) during three years, from inception (2013-2016), and to collect the identities of the investors in all successful campaigns.
\end{abstract}

Keywords Equity crowdfunding, Homophily, Ascribed characteristics, Investor-investee dyads,

Entrepreneurs

Paper type Research paper

\section{Introduction}

Equity crowdfunding involves raising capital to finance entrepreneurial projects through the issuance of equity securities by collecting small amounts from a large number of investors via dedicated platforms on the Internet (Ahlers et al, 2015; Giudici, 2015). Usually, companies willing to raise equity capital have to issue an offering prospectus that market authorities will audit or to rely on the support of professional investors (i.e. business angels or venture capitalists (VCs)). In recent years, the advent of equity crowdfunding has opened a third alternative, which particularly fits the financial needs and characteristics of start-ups and small and medium enterprises (SMEs). According to statistics published by the Cambridge Center for Alternative Finance (see Ziegler et al, 2019), in 2017, equity crowdfunding raised more than $€$ 210 million in Europe, roughly equal to 3\% of venture capital investments in European

\section{JEL Classification - G24, G32}

(C) Giancarlo Giudici, Massimiliano Guerini and Cristina Rossi-Lamastra. Published by Emerald Publishing Limited. This article is published under the Creative Commons Attribution (CC BY 4.0) licence. Anyone may reproduce, distribute, translate and create derivative works of this article (for both commercial and non-commercial purposes), subject to full attribution to the original publication and authors. The full terms of this licence may be seen at http://creativecommons.org/licences/by/4.0/legalcode

The authors acknowledge valuable suggestions from the Guest Editors and from two anonymous reviewers.

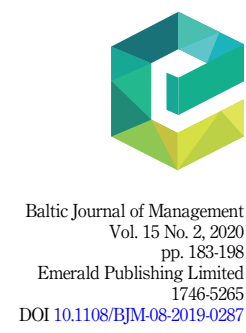


$\mathrm{BJM}$

15,2

184

companies, which totaled $€ 6.4$ billion during the same period (Source: Invest Europe, 2018). This indicates that equity crowdfunding is a viable opportunity to finance new businesses.

Investors in equity crowdfunding are typically nonprofessionals, who contribute to equity crowdfunding campaigns with low amounts of money and have limited bargaining power toward the campaign proponents. Oftentimes, they receive nonvoting shares (Cumming et al., 2019a). Research on equity crowdfunding concurs that these investors pledge money not only in expectation of a financial return but also out of intrinsic motivations, including the willingness of supporting entrepreneurship and innovation. On the other hand, professional investors such as venture capital firms or, to a lesser extent, business angels, require complex agreements, involving veto power, drag along and tag along clauses, as well as appointment of representatives in the board (Kaplan and Strömberg, 2003). It is also worth noting that, in equity crowdfunding, platforms are the only stakeholders responsible of the screening process (Löher, 2017). Platforms may leverage outside parties in vetting and support proponents in marketing their campaign and finding investors.

Until now, the emerging literature on equity crowdfunding has experienced limitations in data availability. Thus, most contributions analyze only one (or a handful of) crowdfunding platforms, or neglect the characteristics of individual investors and proponents, thus missing the fundamental level of the investor-investee dyad. In this paper, we take advantage of the opportunity to access data on the Italian crowdfunding market, from its inception, in the period of 2013-2016 (three years of observations). As to the total of successful equity crowdfunding campaigns on this market, we could collect individual-level data on the identities of the investors and proponents. Such a rich data availability has allowed us to investigate how homophily between investors and proponents shapes the probability that an investor-investee dyad forms, namely that an investor finances a campaign proposed by a given proponent. Scholars in sociology define homophily as the individuals' tendency to form ties with similar alters (see the seminal contributions by McPherson et al., 2001, and Kossinets and Watts, 2009; on the role of homophily in entrepreneurship, see Reuf et al., 2003). Grounding in homophily theory, our main insight is that investors prefer proponents that are similar to them along an array of individual characteristics, and we postulate that these similarities drive the formation of investor-investee dyads.

In accordance with the literature on homophily, we focus on three main individual characteristics, which scholars have recognized as crucial in triggering homophily mechanisms. Specifically, we consider individuals' similarity in age, gender and geographical location (hereafter: geographical proximity). Age and gender are two fundamental ascribed characteristics (see, e.g. Ferrante, 2014, p. 200), that is, characteristics that individuals attained at birth or through the aging process and that they can neither control nor choose. Scholars concur that these characteristics shape the matching processes among individuals, even in business contexts (Piva and Rossi Lamastra, 2018; Barbi and Mattioli, 2019). In a similar vein, research on geographical proximity (Guenther et al., 2018) shows that individuals prefer to tie with their geographical proximates, who they perceive as more similar to them in that they have been exposed to the same formal (e.g. attending the same local schools or being subject to the same local regulations) and informal (e.g. sharing the local cultures and values) institutions. In brief, there is ample consensus that similarity in gender, age and geographical location creates conditions in which connections are more easily established. Accordingly, it is both interesting and relevant to investigate their role in equity crowdfunding.

However, the strength of homophily mechanisms varies depending on the context. In particular, evidence exists that individuals tend to attribute more value to the similarity of the other individuals, the higher the uncertainty and the information asymmetries, which enhance their perception of the risk of opportunistic behavior (see, e.g. Greenberg and Mollick, 2017; Vismara et al., 2017 and Malaga et al., 2018 for a discussion of this effect as to gender similarity) and, therefore, hamper the creation of interpersonal trust. Along this line of 
reasoning, it is interesting to study whether the effects of homophily are stronger in contexts where individuals perceive a higher risk of opportunistic behavior and a lack of trust. Overall, information asymmetries are remarkable in equity crowdfunding campaigns, while trust is hard to develop (Giudici, 2015; Vismara, 2016). However, contingencies influence these general conditions. Accordingly, we posit that the role of homophily in the formation of investor-investee dyads in equity crowdfunding is particularly important when investors perceive the risk of opportunistic behaviors by proponents as particularly high. We argue that this perception depends, among other things, on the level of opportunism existing in the geographical area where proponents of a campaign reside (i.e. "local opportunism"). Indeed, in the absence of information, an investor associates the level of opportunism of local residents with that of the proponent $\mathrm{s} / \mathrm{he}$ is considering to finance.

In the empirical part of the paper, we take advantage of a hand-collected database of 384 equity crowdfunding investments in 13 Italian start-ups carried out by 361 Italian investors. Our empirical approach is at the dyad-level of analysis. Namely, we assess whether an investor-investee dyad forms if homophily exists between investors and investees, namely the board members of the start-ups launching equity crowdfunding campaigns (i.e. the proponent of these campaigns). To this end, we consider all the possible combinations between the 361 investors and the 13 start-ups in our sample, resulting in 4,693 investor-investee dyads. The results highlight a significant effect of geographical proximity and age similarity in explaining the probability that an investor-investee dyad forms, that is, that an investor finances a campaign. In other words, crowd investors are more likely to support campaigns in start-ups whose board members are similar in age and reside in neighboring cities. On the other hand, we do not detect any significant effect related to gender. Moreover, these effects are particularly relevant if the board members are located in areas characterized by a high risk of possible opportunistic behavior, that is, scarce civic responsibility and low sense of citizenship.

The paper proceeds as follows. In the next section, we acknowledge the most relevant contributions in the emerging academic literature on equity crowdfunding. Section 3 introduces our theoretical hypotheses. Section 4 describes the methodology and the data sample. Section 5 introduces the empirical analysis while Section 6 concludes with a discussion about the results of the study and some implications.

\section{Review of the related literature}

Despite such a rapid development of the phenomenon, the current academic debate on equity crowdfunding is still in its infancy and leaves ample room for further research (Mochkabadi and Volkmann, 2020). Most of the contributions explore the determinants of the success of equity crowdfunding campaigns and the amount of money raised (Ralcheva and Roosenboom, 2019). Correlations are found with the characteristics of the board of the issuing company, in terms of education and social capital (Ahlers et al., 2015; Barbi and Mattioli, 2019), gender issues (Malaga et al., 2018), age (Borello et al., 2019), the fraction of equity capital retained by the founders (Vismara, 2016), the pledges accumulated in the first week of the campaign (Vulkan et al., 2015), updates posted by the issuing company during the campaign (Block et al., 2018).

Giudici (2015) underpins the threats of equity crowdfunding for small investors. First, crowdfunders are unsophisticated investors, and thus they are likely unable to provide value-added activities typically brought by professional investors (e.g. business angels and VCs). Second, investing in equity capital of small entrepreneurial ventures is very risky; investors must trust in the due diligence outcome made by web platforms (or cannot rely on any due diligence activity at all) and the risk of opportunistic behavior and moral hazard is high. Third, the management of crowd-backed start-ups is complex, since these firms lack competences, time and resources to manage a wide plethora of investors, this challenging the usual corporate governance rules. Fourth, currently no compelling evidence exists about the "wisdom of the crowd" in selecting successful ventures. 
$\mathrm{BJM}$

15,2

A literature stream that is close to the objective of our work is exploring who are the investors in equity crowdfunding projects and what are their motivations. Anecdotal evidence suggests that they are individuals (and institutions) that aim at participating in innovative projects, obtaining recognition and even fun, joining a community with similar priorities, being among the pioneers of a new business and expanding their personal network. Mohammadi and Shafi (2018) analyze 2,537 bids submitted by 1,979 investors on the Swedish platform FundedByMe. They find that women are less prone to invest in high-tech ventures and when the equity stake offered is larger, and they seem to "follow" men in the investment decisions. Hervè et al. (2019) also find that women invest less in the riskiest investments, but more in safer ones. Investors located in an area considered more "socially friendly" also invest more, but only if the investor is a woman. Hornuf and Schwienbacher (2018) analyze data from four equity crowdfunding platforms in Germany and highlight that investors base their decisions on information provided by the entrepreneur in form of updates during the campaign and by the investment behavior and comments of other crowd investors. Lukkarinen et al. (2016) show that the investment decision criteria implemented by crowd investors are different from those traditionally used by VCs or business angels. Vismara (2018) shows that informational cascades exist in the equity crowdfunding market: contributions in the early days of the campaign are fundamental in attracting other investors and thus increase the probability of fundraising success. Wallmeroth (2019) studies the investors in a specific German crowdfunding platform and documents a relevant heterogeneity of behavior, with a minority of pledgers contributing to the majority of the funds raised.

The matching between the characteristics of entrepreneurs and investors in equity crowdfunding has been analyzed in the literature focusing on gender issues only. Vismara et al. (2017) consider a sample of 58 campaigns from the UK platforms Seedrs and show that the number of male investors is slightly higher in campaigns launched by male-led firms, while female investors strongly prefer firms led by females. Our study extends the perspective, considering a more complete set of investors' characteristics (age, gender, geographical proximity) referred to a whole market. Ewens and Townsend (2020) analyze a sample of deals from the US AngelList platform, open to accredited investors only: they find that male investors express less interest in female entrepreneurs compared to observably similar male entrepreneurs. In contrast, female investors express more interest in female entrepreneurs. Cumming et al. (2019b) study 167 equity crowdfunding campaigns on Crowdcube and investigate whether gender, age, ethnicity and geography affect the fundraising strategies and outcome; yet they are not able to consider the characteristics of investors.

In our study, we analyze all the investments made by investors into different projects and platforms and simultaneously compare a larger set of investor's data (including geographical proximity and age) with the characteristics of the entrepreneur. This substantially increases the significance of our results and adds a valuable contribution to the existing literature.

\section{Hypothesis development: homophily theory and the formation of investor- investee dyads in equity crowdfunding}

From the earlier review, it appears clear that to date the literature has treated proponents and investors of crowdfunding campaigns separately and has left their individual characteristics largely unaddressed. In particular, to the best of our knowledge, no prior work has studied how the characteristics of the entrepreneurs proposing equity crowdfunding campaigns interact with those of the investors to determine the matching between the two and the formation of investor-investee dyads in the equity crowdfunding realm. Accordingly, our research hypotheses revolve around this overarching issue: does homophily between a potential investor $i$ and a proponent of an equity crowdfunding campaign $j$ increase the probability that $i$ invests in $j$ ? 
Scholars concur that homophily plays a crucial role in the entrepreneurship field, in general and in entrepreneurial finance in particular. It drives important entrepreneurial processes, such as the formation of entrepreneurial teams (Reuf et al., 2003) or - more in line with the aims of this work - the matching between VCs and start-ups (Bengtsson and Hsu, 2010). In addition, the notion of homophily and homophily theory closely relate to the financial literature, which increasingly stresses that investment decisions are driven by psychological and social factors, which go beyond pure rational financial considerations (MacGregor et al., 2000; Statman et al., 2008). The notion of homophily is close to the notion of affinity for a company, which Aspara et al. (2008) define as the "extent to which an individual perceives a positively affective congruence" between the venture and his self/identity. Aspara and Tikkanen (2011) posit that individuals with an affinity relationship with a company tend to give preferential and supportive treatment to the company, investing in its stock beyond its expected financial return.

Building on the earlier research, we state that homophily mechanisms are of paramount importance in driving investment decisions in equity crowdfunding. Indeed, equity campaigns are mostly promoted by proponents without a track record, while - contrary to venture capital funds and business angels - crowdfunding investors have limited possibility to engage in due diligence activity and to collect private information about the venture. They rely on the (limited) public information posted on crowdfunding portals. Thus, homophily, in terms of similarity between investors and proponents, helps in reducing uncertainty and molding information asymmetries. In addition, it also breeds trust, thus increasing the probability that an investment relation between an investor and a proponent emerges. In other words, when recognizing similarities in proponents, investors feel reassured about their unobservable characteristics and their trustworthiness. In sum, they resort to these similarities to compensate for information asymmetries.

More specifically, homophily theory stresses the importance of similarities in individuals' age and gender, together with that of similarity in geographical locations, as reflected in geographical proximity (see again Reuf et al., 2003). Accordingly, we state that the probability that investor $i$ finances the campaign $j$ increases if the investor $i$ and the proponents of the campaign $j$ are geographically proximate (Hypothesis H1), have the same gender (Hypothesis $\mathrm{H} 2$ ) and belong to the same age cohort (Hypothesis H3). In short, we assume that investors' decisions are driven by their homophily with proponents along the crucial dimensions of gender, age similarity and geographical proximity.

As we explained in Section 1, the importance of similarity in driving investors' decision depends on investors' perception of the risk of opportunism by proponents, which, in turn, depends, among other things, on the level of opportunism existing in the geographical area where proponents of a campaign reside (i.e. "local opportunism"). Indeed, in the absence of information, an investor associates the level of opportunism of local residents to that of the proponent $\mathrm{s} / \mathrm{he}$ is considering to finance. These arguments are in line with the work of Giudici et al. (2018), which explores how characteristics of the local environment shape investment dynamics in reward-based crowdfunding. The authors note that when running a crowdfunding campaign, entrepreneurs leverage, build and draw upon local resources (Brown et al., 2019), so that the success of a crowdfunding campaign crucially depends on local characteristics. Social capital built at the local level is one of these resources: it is the goodwill available to individuals from the structure and content of their social relations (Adler and Kwon, 2002), in terms of network connections and assets that may be mobilized (Nahapiet and Ghoshal, 1998). At the local level, collective social capital is an environment feature, permitting cooperation and enhancing economic activity and resource mobilization (Coleman, 1988).

As we discussed earlier, the presumption that proponents do not indulge in opportunistic behavior and are trustworthy is particularly important for equity crowdfunding investors.
Matchings in equity crowdfunding 
BJM

15,2

188

Homophily along the gender, age and geographical dimensions compensates for information asymmetries and creates trust, but we expect that these effects are less intense when proponents reside in areas where the risk of opportunistic behavior is lower (Hypothesis H4). Indeed, in these areas, investors use the trustworthiness of local residents to estimate how trustworthy are the venture initiators. In addition, investors perceive projects proposed by proponents residing in areas with low risk of opportunism as less uncertain, while this local characteristic acts as a positive signal of the (unobserved) qualities of the proponents and of their projects. Thus, according to Hypothesis H4, we expect that the homophily between investors and proponents is less salient if the latter resides in areas where the risk of opportunism is lower.

\section{Data and methodology}

We test our hypotheses by taking advantage of a hand-collected database comprising 384 equity crowdfunding investments carried out by 361 Italian investors in 13 equity crowdfunding campaigns. These campaigns have been launched by Italian start-ups from January 2013 to June 2016 on seven equity crowdfunding platforms. We obtained data from the official Register of Business companies in Italy (Registro delle Imprese), which allowed to unambiguously identify all investors starting from their tax ID codes. The sample covers $100 \%$ of the campaigns successfully funded during the considered period and $100 \%$ of the investors. Unfortunately, we are not able to observe pledges by investors in unsuccessful campaigns. During the considered period, 12 unsuccessful campaigns have been registered. In nine cases these campaigns have been backed by less than five investors. Therefore, the possible bias in the results is negligible.

According to Ziegler et al. (2019), Italian crowdfunding volumes between 2013 and 2016 were estimated at a total of $€ 7.6$ million, supporting the notion of a market at its early stages. Equity crowdfunding was introduced in Italy by a specific law at the end of 2012, in derogation to the general rules for public offerings, and came into force in 2013. According to the law, up to 2016 only innovative start-ups were allowed to raise equity capital on the Internet. Under the Italian law, innovative start-ups are young (i.e. less than five years old) limited liability companies operating in technology-related businesses. They have to comply with one of the following three requirements: (1) be holder, depositary or licensee of a patent or the owner and author of a registered software; (2) at least one-third of employees must hold a $\mathrm{PhD}$ or a research tenure (or at least two-third must hold a MSc degree); (3) investments in R\&D should account for at least $15 \%$ of the revenues (or operating costs if they exceed the revenues). Innovative start-ups cannot distribute dividends and cannot be listed on a stock exchange. The annual revenues must be lower than $€ 5$ million and the company must not be originated from a spin-off or a merger of pre-existing operations (Giraudo et al., 2019; Giudici et al., 2019). Interestingly, contrary to other countries, Italy did not impose any restriction on the maximum amount to be invested in equity crowdfunding by a single citizen. Yet it is required that at least $5 \%$ of the campaign proceeds are provided by professional investors (VCs, business angels, funds, incubators, investment vehicles).

We think that our sample period is an interesting case study, because of two reasons. First, we have the opportunity to observe the first stage of development of a new industry and to analyze how relations are established (and trust is created) in an emerging and growing business, when investors cannot base on track record to make their decisions. Second, we have the unique opportunity to observe the generalities of investors for all the active platforms in the market, since these data are publicly available in Italy.

Our empirical approach is at the dyad-level of analysis. Namely, we assess whether an investor-investee dyad forms if homophily exists between investors and investees, namely the board members of the start-ups launching equity crowdfunding campaigns (i.e. the 
proponents of these campaigns). According to Garg and Furr (2017), we focus on board members because they are in charge of the management of the company and their role in the future is fundamental to ensure that the money raised during the crowdfunding campaign will be invested efficiently. Therefore, investors will scrutinize their identities in deciding whether to fund the start-up or not. Moreover, it is worth considering that, most of the time, board members in a start-up include the initial founders.

We consider all the possible combinations between the 13 start-ups and the 361 investors in our sample, resulting in 4,693 potential (384 realized and 4,309 unrealized) investorinvestee dyads (for a similar approach in the context of corporate venture capital investments, see Dushnitsky and Shaver, 2009; see also Lin and Viswanathan, 2016, who study loans on the P2P lending platform Prosper.com). We run Probit models (with errors clustered at the investor level), where the dependent variable (Realized tie) is the probability that investor-investee dyad forms, that is, that an investor $i$ and a start-up $j$ will form an investment relationship.

Our main independent variables refer to the geographical proximity between the investor $i$ and the board members of the startup $j$, their homophily in terms of gender and age and the local level of opportunism associated to the location of the start-up's board members. From the official Register of the Italian companies, we collected data about gender, age, place of residence of both investors and board members. Following D'Este et al. (2013), we introduce the Geographical proximity, computed as the inverse of the square root of the minimum distance between the location of the investor $i$ and of the board members of the start-up $j$. Same gender is defined as a dummy variable that equals 1 if an investor $i$ and at least one of the board members of the start-up $j$ belong to the same gender. Same age class is a dummy variable equal to 1 if an investor $i$ and at least one of the board members of the start-up $j$ belong to the same age class (i.e. age difference less than 10 years). Data on the level of local opportunism are obtained from the Italian National Statistical Office (ISTAT). More specifically, we measure the tendency of the population that resides in the same area of the board members to behave opportunistically by considering the local (i.e. at the NUTS3 level, according to the Nomenclature of Territorial Units for Statistics from Eurostat) evasion rate of the fee that is due by televisions' owners. In Italy - as in many other European countries - a national law forces all households that own a television equipment to pay a television fee, the so called Canone Rai. As an external agent can hardly observe the private ownership of a television equipment, the extent to which households in an area do not denounce their possession of a television and do not pay such a fee may be considered as a good proxy of their tendency to behave opportunistically (Ghio et al., 2019). It is worth noting that more than $97 \%$ of Italian households hold at least a television equipment (Auditel-Censis, 2018). So, it is very unlikely that differences across regions in the evasion rate are due to differences in the number of households that did not own a television equipment.

Finally, borrowing from the existing literature (Ahlers et al., 2015; Vismara, 2016, 2018; Vismara et al., 2017; Borello et al., 2019), we control for a number of variables at the project(Target and Minimum investment), investor- (Investor age) and board member level (Board female, Board size and Board age). Platform-level dummies are also included in the regressions to take into account for differences in the screening criteria and visibility. We describe the variables included in our models in Table 1 . Table 2 reports summary statistics, and Table 3 lists the correlations.

\section{Results and implications}

\subsection{Main results}

Table 4 shows the results from Probit regressions on the probability that an investorinvestee dyad forms, that is, that an investor $i$ forms an investment tie with the start-up $j$. 


\section{BJM 15,2}

190

Variables description
Variable Description

Dependent variable

Realized tie

Main independent

variables

Geographical

proximity

Same gender

Same age class

Local opportunism

Controls

Target

Minimum investment

Board female

Dummy variable that equals 1 if an investor $i$ and a start-up $j$ form an investment relationship

Inverse of the square root of the minimum distance between the location of the investor $i$ and of the board members of the start-up $j$ (D'Este et al., 2013)

Dummy variable that equals 1 if an investor $i$ and at least one of the board members of the start-up $j$ belong to the same gender

Dummy variable that equals 1 if an investor $i$ and at least one of the board members of the start-up $j$ belong to the same age class (i.e. age difference less than 10 years) Dummy variable that equals 1 if the proportion of households (in the NUTS3 area in which the board members reside) that did not pay the television license fee in 2011 is higher than the average value in the sample (Ghio et al., 2019)

Minimum target capital of the equity crowdfunding campaign

Minimum investment required in order to subscribe the shares of the start-up $j$ during the equity crowdfunding campaign

Dummy variable that equals 1 if at least one of the board members of the start-up $j$ is female

Board size $\quad$ Number of board members of the start-up $j$

Board age

Investor age
Average age of the board members of the start-up $j$

Age of the investor $i$

\begin{tabular}{|c|c|c|c|c|c|}
\hline Variable & Observations & Mean & Std. Dev & Min & Max \\
\hline Realized tie & 4,693 & 0.08 & 0.27 & 0 & 1 \\
\hline Geographical proximity & 4,693 & 0.13 & 0.23 & 0.01 & 1 \\
\hline Same gender & 4,693 & 0.79 & 0.41 & 0 & 1 \\
\hline Same age class & 4,693 & 0.50 & 0.50 & 0 & 1 \\
\hline Local opportunism & 4,693 & 0.54 & 0.50 & 0 & 1 \\
\hline Target & 4,693 & 213.19 & 148.36 & 0.19 & 520 \\
\hline Minimum investment & 4,693 & 0.44 & 0.45 & 0 & 1.6 \\
\hline Board female & 4,693 & 0.23 & 0.42 & 0 & 1 \\
\hline Board size & 4,693 & 2.31 & 1.32 & 1 & 5 \\
\hline Board age & 4,693 & 42.68 & 7.63 & 30.50 & 58.50 \\
\hline Investor age & 4,693 & 46.30 & 12.16 & 20 & 87 \\
\hline
\end{tabular}

Table 2.

Summary statistics

Note(s): The variables are defined as in Table 1. Sample: 4,693 potential investor-investee dyads between investors and start-ups (384 realized and 4,309 unrealized)

Model 1 includes controls and the three homophily variables (i.e. Geographical proximity, Same gender and Same age class). Model 2 adds Local Opportunism and its interaction with the three homophily variables.

Results shown in Model 1 of Table 4 are in line with $\mathrm{H} 1$ and H3. Both coefficients of Geographical proximity and Same age class are indeed positive and strongly statistically significant (at 1\%). Conversely, we do not find support for H2, as the coefficient of Same gender is not significant at conventional levels.

Let us turn attention to Model 2. First, the perceived risk of opportunistic behavior of start-up's board members is negatively associated to the likelihood of an investment tie 


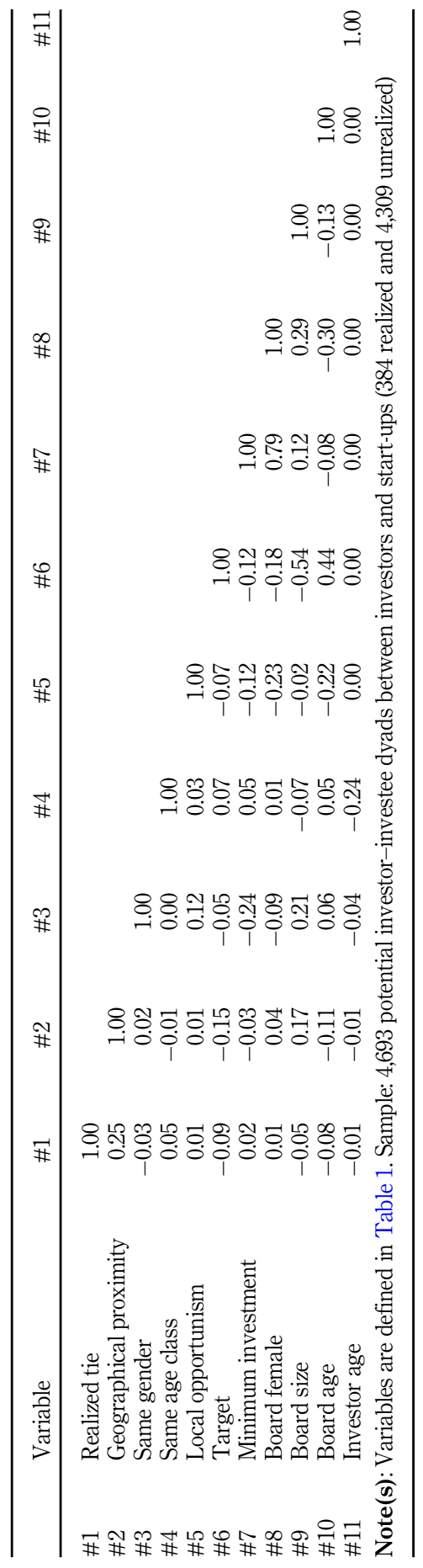

Matchings in crowdfunding

191

Table 3. Correlation matrix 
$\mathrm{BJM}$
15,2

192

\begin{tabular}{|c|c|c|}
\hline & Model 1 & Model 2 \\
\hline Geographical proximity & $\begin{array}{l}1.311 * * * \\
(0.092)\end{array}$ & $\begin{array}{l}1.020^{* * * *} \\
(0.138)\end{array}$ \\
\hline Same gender & $\begin{array}{l}0.017 \\
(0.060)\end{array}$ & $\begin{array}{l}0.081 \\
(0.117)\end{array}$ \\
\hline Same age class & $\begin{array}{l}0.278^{* * * *} \\
(0.058)\end{array}$ & $\begin{array}{l}0.085 \\
(0.081)\end{array}$ \\
\hline Target & $\begin{array}{l}-0.002 * * * * \\
(0.000)\end{array}$ & $\begin{array}{l}-0.002^{* * * *} \\
(0.000)\end{array}$ \\
\hline Minimum investment & $\begin{array}{l}0.239 \\
(0.148)\end{array}$ & $\begin{array}{l}0.271^{*} \\
(0.163)\end{array}$ \\
\hline Board female & $\begin{array}{l}-0.208 \\
(0.173)\end{array}$ & $\begin{array}{l}-0.301 \\
(0.191)\end{array}$ \\
\hline Board size & $\begin{array}{l}-0.245^{* * * *} \\
(0.047)\end{array}$ & $\begin{array}{l}-0.250^{\text {**** }} \\
(0.048)\end{array}$ \\
\hline Board age & $\begin{array}{l}-0.013^{* *} \\
(0.006)\end{array}$ & $\begin{array}{l}-0.017^{* * * *} \\
(0.007)\end{array}$ \\
\hline Investor age & $\begin{array}{l}0.003^{*} \\
(0.002)\end{array}$ & $\begin{array}{l}0.004^{* * *} \\
(0.002)\end{array}$ \\
\hline Local opportunism & - & $\begin{array}{l}-0.306^{*} \\
(0.170)\end{array}$ \\
\hline Geographical proximity * local opportunism & - & $\begin{array}{l}0.531^{* * * *} \\
(0.167)\end{array}$ \\
\hline Same gender * local opportunism & - & $\begin{array}{l}-0.098 \\
(0.145)\end{array}$ \\
\hline Same age class * local opportunism & - & $\begin{array}{l}0.397^{* * * *} \\
(0.123)\end{array}$ \\
\hline Constant & $\begin{array}{l}-0.507^{* * *} \\
(0.208)\end{array}$ & $\begin{array}{l}-0.220 \\
(0.289)\end{array}$ \\
\hline Platform dummies & YES & YES \\
\hline$N$ & 4,693 & 4,693 \\
\hline Log-likelihood & -1157.1 & -1147.5 \\
\hline Pseudo $R^{2}$ & 0.129 & 0.137 \\
\hline
\end{tabular}

Note(s): The table reports the Probit regression estimates on the probability that an investor-investee dyad forms, that is, that investor $i$ creates an investment tie with the start-up $j$. Variables are defined in Table 1. Sample: 4,693 potential investor-investee dyads between investors and start-ups (384 realized and 4,309 unrealized)

Table 4. Standard errors are in brackets. The asterisks *** and *** indicate significance at the $10 \%, 5 \%$, and $1 \%$ level, Regression results respectively

formation. The coefficient of Local Opportunism is indeed negative and significant at $10 \%$. Furthermore, both the interaction terms Geographical proximity * Local Opportunism and Same age class * Local Opportunism are positive and strongly significant (at 1\%), suggesting that geographical proximity and similarity in age are particularly important in investment tie formation when the perceived risk of opportunistic behavior is high. Conversely, similarity in gender does not seem to play any significant role.

However, given the nonlinear specification of the Probit model, looking at the significance and the magnitude of the estimated coefficients is not sufficient to assess the impact of the variables of interest and the existence of interactive effects. To ascertain whether the importance of geographical proximity, gender similarity and age similarity in reducing the negative effect of local opportunism on the creation of investment ties, we report in Table 5 the average marginal effects (i.e. the average increase in the probability of tie formation due to a one unit increase in the variable of interest) of the three homophily 
variables when Local Opportunism equals 0 (perceived low risk of opportunism) and 1 (perceived high risk of opportunism) respectively. We find that when the risk of opportunism is very low (high), a 0.1 increase in the measure for geographical proximity leads to a $1.4 \%$ $(1.9 \%)$ significant increase in the probability of tie formation. Then, when the risk of opportunism is very high, age similarity leads to an increase of $5.9 \%$ in the probability of tie formation, while we do not detect any significant effect when the level of opportunism is perceived as low.

\subsection{Robustness checks}

To further validate our findings, we run a number of robustness checks. First, our measure for opportunism might reflect differences in local household income (the lower the income, the lower the propensity of households to own a television), rather than differences in the tendency to behave opportunistically. In Model 3 (see Table 6), we control for local household income by including the GDP per capita at the local level. Results concerning the main variables of interest are very similar to those shown in Table 4 . Second, certain individual investors could be potentially more likely to choose a campaign because of the presence of institutional investors (i.e. a bank, an investment company or a venture capital firm). Although the presence of a generic professional investor is a necessary condition to validate the issue (see Section 4), specialized institutional investors could provide a special signal to the crowd. Yet, it is worth noting that in most platforms included in the sample, it is not possible for investors to know the identity of early investors in a campaign. However, in Model 4 of Table 6, we included a dummy variable that equals 1 if there is at least one institutional investor in the campaign. The coefficient of this additional control is not significant, while results concerning the main variables of interest are very similar to those reported in Table 4.

One may argue more in general that unobserved characteristics at both the investor- and start-up level could drive our results. For instance, some start-ups might be more likely to self-select into equity crowdfunding (Cumming et al., 2019b) or the investment choices of individual investors might be driven by their personal preferences. To deal with these potential problems, we used an alternative estimation methodology, a conditional Logit regression model. The conditional Logit model allows to control for latent investor and start-up characteristics conditioning out their fixed effects (Hosmer et al., 2013) and has been widely used in the literature studying the formation of collaborative ties (e.g. Dushnitsky and Shaver, 2009). When conditioning by investor (start-up), variables that do not vary at the investor (start-up) level, that is, Investor age (Local opportunism, Target, Minimum investment, Board female, Board size and Board age) are dropped. The results are shown in Model 5 (investor-level fixed effects) and Model 6 (start-up-level fixed effects) of Table 6 and are similar to those presented in Table 4.

\begin{tabular}{lcc}
\hline Average marginal effect of & Opportunism $=0$ & Opportunism $=1$ \\
\hline Geographical proximity & $0.143^{* * * *}$ & $0.192^{* * * *}$ \\
Same gender & $(0.021)$ & $(0.014)$ \\
& 0.011 & -0.002 \\
Same age class & $(0.016)$ & $(0.009)$ \\
& 0.011 & $0.059^{* * * *}$
\end{tabular}

Note(s): The table reports the marginal effects for the Probit regression estimates on the likelihood that investor $i$ creates an investment tie with the start-up $j$. Variables are defined in Table 1. Sample: 4,693 potential investor-investee dyads between investors and start-ups (384 realized and 4,309 unrealized) Standard errors are in brackets. The asterisks *** indicate significance at the $1 \%$ level
Matchings in equity crowdfunding 
BJM
15,2

194

Table 6.

Robustness checks

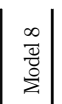

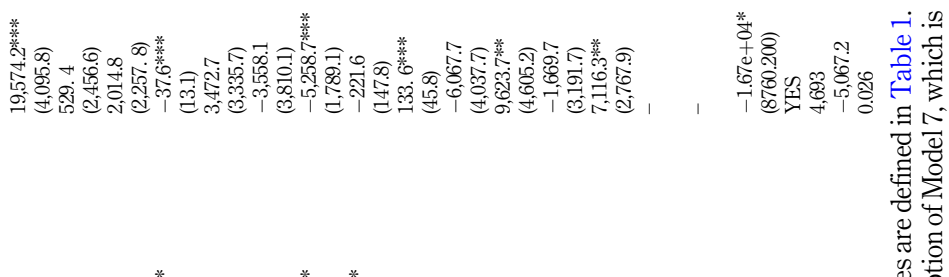

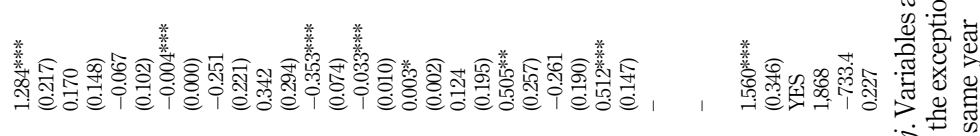

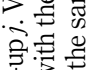

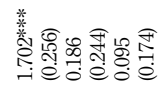

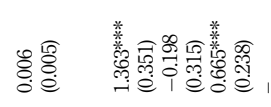
츤

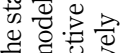
至害空

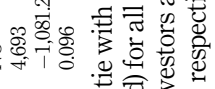
공 눙 $\frac{2}{4}$

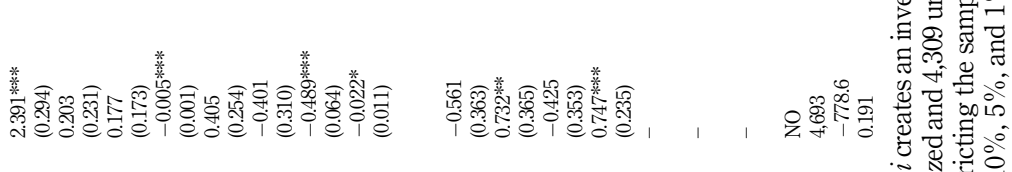

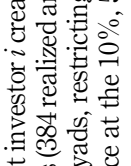

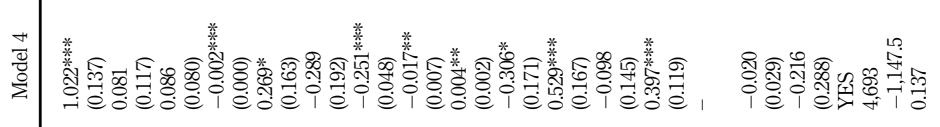

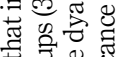

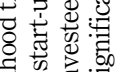

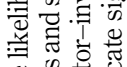
을 등 \&

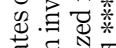

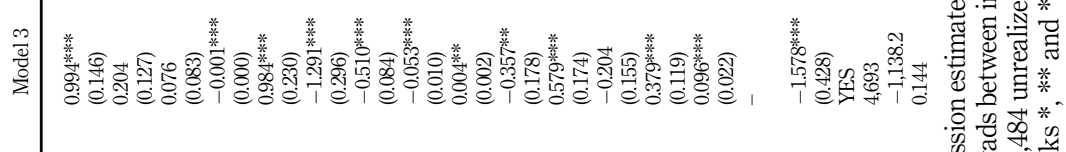

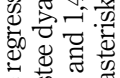
范实 胥. 卷 过苛焉 त्ञ क्षे क्षै

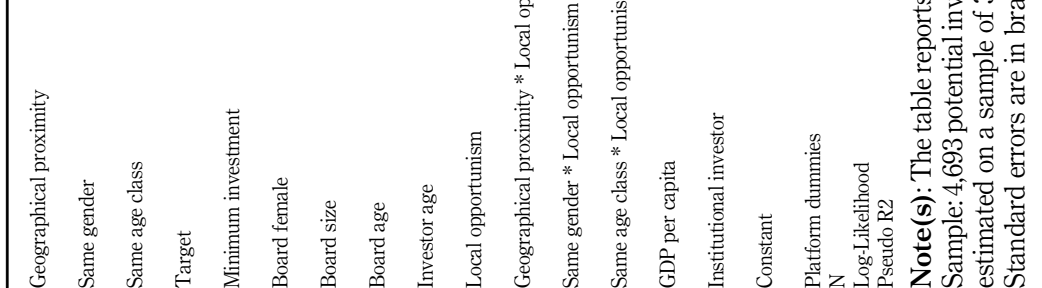

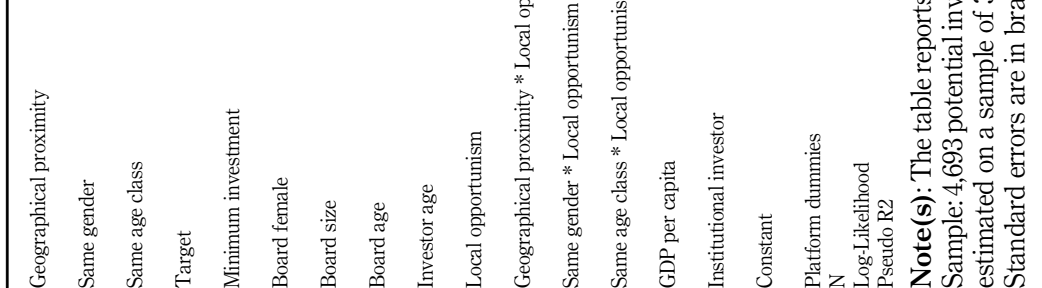

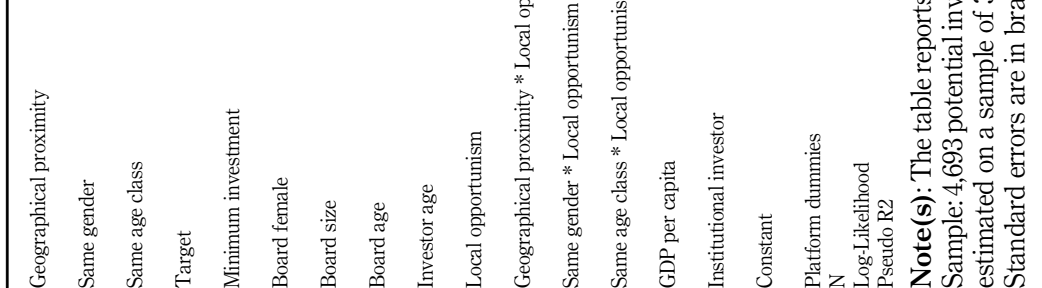

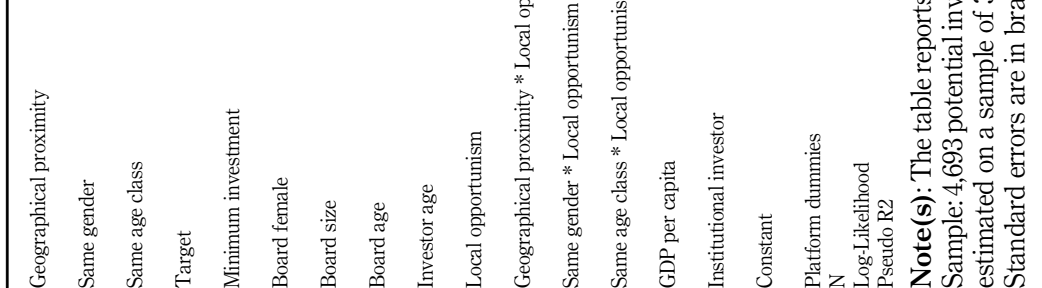


Furthermore, it is worth noting that our sample is made of 4,693 investor-investee dyads based on all the possible combinations between the 361 investors that made at least an investment in the period of 2013-2016 and the 13 start-ups that launched a campaign in the same three-year period. We have therefore implicitly assumed that, for instance, an investor who made an investment in 2016 would have considered investing in campaigns posted in 2013 (and vice versa). In Model 7 of Table 6, following Lin and Viswanathan (2016), we built potential but unrealized dyads by considering only start-ups and investors that were active in the same year. Results are still in line with those shown in Table 4.

Finally, we consider an alternative specification with the invested amount as the dependent variable and we run a Tobit model. Results are shown in Model 8 of Table 6, confirming previous findings.

\section{Conclusion: discussion and implications}

In this paper, we focus on the matching between entrepreneurs and potential investors in equity crowdfunding. We contribute to the literature by studying how the matching characteristics of investors and proponents explain fundraising process outcomes.

Our results suggest a significant effect of geographical proximity and age similarity in explaining the probability that an investor finances a start-up. These effects are particularly relevant in the case of perceived high risk of opportunistic behavior, in local contexts where civic engagement is lower. Conversely, we do not detect any significant effect related to gender identity.

In equity crowdfunding, information asymmetries and moral hazard are relevant: we show that homophily in terms of geographical proximity and age is leveraged in creating trust, which facilitates investment ties. To date, homophily between entrepreneurs and investors in equity crowdfunding campaigns has been analyzed in very specific settings. Ewens and Townsend (2020) focus on the US platform AngelList, which is accessible to accredited investors only; Vismara et al. (2017) introduce descriptive statistics using data from the Seedrs equity crowdfunding platform, while we are the first to analyze an entire market at the stage of inception, accessible to the general public. This allows us to examine the behavior of investors on a full scale, without biases for unobservable actions, through a multivariate analysis with a number of robustness checks.

Our contribution is relevant for both entrepreneurs and managers of crowdfunding platforms. To start, through the lens of homophily we are able to understand how investment dyads are created by leveraging investor-investee ties. Second, we add value to the model by considering the moderating role of the local social capital, affecting the propensity of opportunistic behavior. In the absence of information, equity investors associate the level of opportunism of local residents to that of the proponent $\mathrm{s} / \mathrm{he}$ is considering to finance. We believe that this is an interesting result that may be explored also in other markets for "alternative" finance (private equity, venture capital, digital token offerings and initial coin offerings) and more broadly in other contexts (dating platforms, peer-to-peer transactions platforms) where people and organizations are matched at the long distance. Start-up businesses, originated in areas where the perceived risk of opportunistic behavior is larger and in countries with less cosmopolitan culture, will probably experience more troubles in accessing finance from banks and institutional investors; therefore crowdfunding may reduce the funding gap, to the extent that it leverages on homophily between entrepreneurs and funders from the same place and from the same age experience, enhancing the probability of investor-investee matching. A deeper study on alternative and/or complementary measures of the local level of opportunism is probably worthy.

Third, we derive relevant practical implications for entrepreneurs and crowdfunding platforms: according to our findings, in the absence of specific marketing efforts, the matching between proponents and investors will be strongly influenced by homophily. If
Matchings in equity crowdfunding 
BJM

15,2

platforms and entrepreneurs are willing to expand their base of potential funders, they should work to reduce information barriers toward investors who are geographically far and younger (or older) compared to the venture directors. The result also suggests that crowdfunding portals should avoid to display campaigns promoted by entrepreneurs with the same characteristics, not to provoke a "cannibalization" effect. A mix of entrepreneurial projects founded by heterogeneous types of individuals will maximize the opportunity to create linkages and investment ties with the market.

Like any other empirical investigation, our study has some limitations. The analysis covers the period of inception of the equity crowdfunding industry in Italy. We highlight that, during this initial stage, equity crowdfunding platforms were worried about attracting a number of investors and start-ups in order to create a large audience and a relevant network of potential investors. This is confirmed by interviews with the platform managers. The literature on platforms (see e.g. Cusumano et al., 2019) extensively discusses how platforms, in the start-up phase of a new industry, tend to target a large audience in order to "bring both sides on board" and overcome the chicken-egg problem. Therefore, we tend to exclude that in our context, platform managers actively spent marketing efforts to attract targeted age- and geography-wise potential investors, this introducing a bias in the results.

The equity crowdfunding industry in Italy grew up substantially in 2017 and 2018; therefore, more robust indications could be obtained in the future extending the period of the observations. Another possible direction to extend our knowledge on equity crowdfunding investments is to consider possible ties between entrepreneurs and professional investors, whose decisions could be driven by different factors. We leave these issues to future research.

\section{References}

Adler, P.S. and Kwon, S. (2002), "Social capital: prospects for a new concept", Academy of Management Journal, Vol. 27 No. 1, pp. 17-40.

Ahlers, G.K., Cumming, D., Günther, C. and Schweizer, D. (2015), "Signaling in equity crowdfunding", Entrepreneurship: Theory and Practice, Vol. 39 No. 2, pp. 955-980.

Aspara, J. and Tikkanen, H. (2011), "Individuals' affect-based motivations to invest in stocks: beyond expected financial returns and risks", The Journal of Behavioral Finance, Vol. 12 No. 2, pp. 78-89.

Aspara, J., Olkkonen, R., Tikkanen, H., Moisander, J. and Parvinen, P. (2008), "A theory of affective self-affinity: definitions and application to a company and its business", Academy of Marketing Science Review, Vol. 12 No. 3, pp. 1-37.

Auditel-Censis (2018), "1 Rapporto Auditel-Censis. Convivenze, relazioni e stili di vita delle famiglie italiane", available at (in Italian): http://www.censis.it/sites/default/files/downloads/Sintesi_3.pdf.

Barbi, M. and Mattioli, S. (2019), "Human capital, investor trust, and equity crowdfunding", Research in International Business and Finance, Vol. 49, pp. 1-12.

Bengtsson, O. and Hsu, D. (2010), "How do venture capital partners match with startup founders?" SSRN Working Paper.

Block, J., Hornuf, L. and Moritz, A. (2018), "Which updates during an equity crowdfunding campaign increase crowd participation?”, Small Business Economics, Vol. 50 No. 1, pp. 3-27.

Borello, G., De Crescenzo, V. and Pichler, F. (2019), "Factors for success in European crowdinvesting", Journal of Economics and Business, Vol. 106 No. 105845.

Brown, R., Mawson, S. and Rowe, A. (2019), "Start-ups, entrepreneurial networks and equity crowdfunding: a processual perspective”, Industrial Marketing Management, Vol. 80, pp. 115-125.

Coleman, J.S. (1988), "Social capital in the creation of human capital", American Journal of Sociology, Vol. 94, pp. S95-S120.

Cumming, D., Meoli, M. and Vismara, S. (2019a), "Investors' choices between cash and voting rights: evidence from dual-class equity crowdfunding", Research Policy, Vol. 48 No. 8, p. 103740. 
Cumming, D., Meoli, M. and Vismara, S. (2019b), "Does equity crowdfunding democratize entrepreneurial finance?", Small Business Economics, doi: https://doi.org/10.1007/s11187-01900188-z.

Cusumano, M.A., Gawer, A. and Yoffie, D.B. (2019), The Business of Platforms: Strategy in the Age of Digital Competition, Innovation, and Power, Harper Business, New York.

D'Este, P., Guy, F. and Iammarino, S. (2013), "Shaping the formation of university-industry research collaborations: what type of proximity does really matter?", Journal of Economic Geography, Vol. 13 No. 4, pp. 537-555.

Dushnitsky, G. and Shaver, J.M. (2009), "Limitations to interorganizational knowledge acquisition: the paradox of corporate venture capital”, Strategic Management Journal, Vol. 30 No. 10, pp. 1045-1064.

Ewens, M. and Townsend, R.R. (2020), “Are early stage investors biased against women?”, Journal of Financial Economics, Vol. 135 No. 3, pp. 653-677.

Ferrante, J. (2014), Sociology: A Global Perspective, 9th ed., Cengage Learning, Andover.

Garg, S. and Furr, N. (2017), "Venture boards: past insights, future directions, and transition to public firm boards", Strategic Entrepreneurship Journal, Vol. 11 No. 3, pp. 326-343.

Ghio, N., Guerini, M. and Rossi Lamastra, C. (2019), "University knowledge and the creation of knowledge-intensive firms at the local level: the moderating effect of cooperative banks", Small Business Economics, Vol. 52 No. 2, pp. 523-543.

Giraudo, E., Giudici, G. and Grilli, L. (2019), "Entrepreneurship policy and the financing of young innovative companies: evidence from the Italian Startup Act”, Research Policy, Vol. 48 No. 9, p. 103801.

Giudici, G., Guerini, M. and Rossi Lamastra, C. (2018), "Reward-based crowdfunding of entrepreneurial projects: the effect of local altruism and localized social capital on proponents' success", Small Business Economics, Vol. 50 No. 2, pp. 307-324.

Giudici, G., Guerini, M. and Rossi Lamastra, C. (2019), "The creation of cleantech startups at the local level: the role of knowledge availability and environmental awareness", Small Business Economics, Vol. 52 No. 4, pp. 815-830.

Giudici, G. (2015), "Equity crowdfunding of an entrepreneurial activity", in Audretsch, D., Lehmann, E., Meoli, M. and Vismara, S. (Eds), University Evolution, Entrepreneurial Activity and Regional Competitiveness, Springer.

Greenberg, J. and Mollick, E. (2017), "Activist choice homophily and the crowdfunding of female founders", Administrative Science Quarterly, Vol. 62 No. 2, pp. 341-374.

Guenther, C., Johan, S. and Schweizer, D. (2018), "Is the crowd sensitive to distance?-how investment decisions differ by investor type”, Small Business Economics, Vol. 50 No. 2, pp. 289-305.

Hervé, F., Manthé, E., Sannajust, A. and Schwienbacher, A. (2019), "Determinants of individual investment decisions in investment-based crowdfunding", Journal of Business Finance and Accounting, Vol. 46, pp. 762-783.

Hornuf, L. and Schwienbacher, A. (2018), "Market mechanisms and funding dynamics in equity crowdfunding", Journal of Corporate Finance, Vol. 50, pp. 556-574.

Hosmer, D.W., Lemeshow, S.A. and Sturdivant, R.X. (2013), Applied Logistic Regression, 3rd ed., Wiley, Hoboken, NJ.

Invest Europe (2018), European Private Equity Activity Report and Data 2017, Brussels.

Kaplan, S.N. and Strömberg, P. (2003), "Financial contracting theory meets the real world: an empirical analysis of venture capital contracts", The Review of Economic Studies, Vol. 70 No. 2, pp. 281-315.

Kossinets, G. and Watts, D.J. (2009), "Origins of homophily in an evolving social network", American Journal of Sociology, Vol. 115 No. 2, pp. 405-450.

Lin, M. and Viswanathan, S. (2016), "Home bias in online investments: an empirical analysis of an online crowdfunding market", Management Science, Vol. 62 No. 5, pp. 1393-1414. 
BJM

15,2

198
Löher, J. (2017), "The interaction of equity crowdfunding platforms and ventures: an analysis of the preselection process", Venture Capital, Vol. 19 Nos 1-2, pp. 51-74.

Lukkarinen, A., Teich, J.E., Wallenius, H. and Wallenius, J. (2016), "Success drivers of online equity crowdfunding campaigns", Decision Support Systems, Vol. 87, pp. 26-38.

MacGregor, D.G., Slovic, P., Dreman, D. and Berry, M. (2000), "Imagery, affect, and financial judgment", The Journal of Psychology and Financial Markets, Vol. 1 No. 2, pp. 104-110.

Malaga, R., Mamonov, S. and Rosenblum, J. (2018), "Gender difference in equity crowdfunding: an exploratory analysis", International Journal of Gender and Entrepreneurship, Vol. 10 No. 4, pp. 332-343.

McPherson, M., Smith-Lovin, L. and Cook, J.M. (2001), "Birds of a feather: homophily in social networks", Annual Review of Sociology, Vol. 27 No. 1, pp. 415-444.

Mochkabadi, K. and Volkmann, C.K. (2020), "Equity crowdfunding: a systematic review of the literature”, Small Business Economics, Vol. 54 No. 1, pp. 75-118, doi: 10.1007/s11187-018-0081-x.

Mohammadi, A. and Shafi, K. (2018), "Gender differences in the contribution patterns of equitycrowdfunding investors”, Small Business Economics, Vol. 50 No. 2, pp. 275-287.

Nahapiet, J. and Ghoshal, S. (1998), "Social capital, intellectual capital, and the organizational advantage", Academy of Management Review, Vol. 23, p. 242.

Piva, E. and Rossi Lamastra, C. (2018), "Human capital signals and entrepreneurs' success in equity crowdfunding”, Small Business Economics, Vol. 51 No. 3, pp. 667-686.

Ralcheva, A. and Roosenboom, P.G.J. (2019), "Forecasting success in equity crowdfunding", Small Business Economics, in press, doi: https://doi.org/10.1007/s11187-019-00144-x.

Reuf, M., Aldrich, H.E. and Carter, N.M. (2003), "The structure of founding teams: homophily, strong ties, and isolation among U.S. entrepreneurs", American Sociological Review, Vol. 68 No. 2, pp. 195-222.

Statman, M., Fisher, K.L. and Anginer, D. (2008), "Affect in a behavioral asset pricing model", Financial Analysts Journal, Vol. 64 No. 2, pp. 20-29.

Vismara, S., Benaroio, D. and Carne, F. (2017), "Gender in entrepreneurial finance: matching investors and entrepreneurs in equity crowdfunding". in Albert, L. (Ed.), Gender and Entrepreneurial Activity, Edward Elgar, Cheltenham, pp. 271-288.

Vismara, S. (2016), "Equity retention and social network theory in equity crowdfunding", Small Business Economics, Vol. 46 No. 4, pp. 579-590.

Vismara, S. (2018), "Information cascades among investors in equity crowdfunding", Entrepreneurship: Theory and Practice, Vol. 42 No. 3, pp. 467-497.

Vulkan, N., Astebro, T. and Fernandez Sierra, M. (2015), "Equity crowdfunding: a new phenomena”, Said Business School Working Paper 2015-21.

Wallmeroth, J. (2019), "Investor behavior in equity crowdfunding", Venture Capital, Vol. 21 Nos 2-3, pp. 273-300.

Ziegler, T., Shneor, R., Wenzlaff, K., Odorović, A., Johanson, D., Hao, R. and Ryll, L. (2019), The 4th European Alternative Finance Benchmarking Report, Cambridge Center for Alternative Finance, Cambridge.

\section{Corresponding author}

Giancarlo Giudici can be contacted at: giancarlo.giudici@polimi.it

For instructions on how to order reprints of this article, please visit our website:

www.emeraldgrouppublishing.com/licensing/reprints.htm

Or contact us for further details: permissions@emeraldinsight.com 